American Journal of Applied Sciences 5 (12): 1676-1685, 2008

ISSN 1546-9239

(C) 2008 Science Publications

\title{
Fostering ICT Development for Growth: Measuring the Payoffs for Australia and the Asean-5 Countries
}

\author{
${ }^{1}$ Mudiarasan Kuppusamy, ${ }^{2}$ Mosayeb Pahlavani and ${ }^{3}$ Ali Salman Saleh \\ ${ }^{1}$ School of Business, Monash University Malaysia, Malaysia \\ ${ }^{2}$ University of Sistan and Baluchestan, Iran \\ ${ }^{3}$ Faculty of Business and Law, \\ School of Applied Economics, Victoria University, Vic 8001, Australia
}

\begin{abstract}
Over the past few decades the brisk development of information and communication technologies (ICT) has had a phenomenal impact on the economic stability and development of many countries. Empirical studies show that most developed economies have gained significant payoffs (in terms of economic growth) from their ICT investments. This study investigates the hypothesis that ICT-based investment has paid off for Australia and the ASEAN-5 countries (Malaysia, Singapore, Indonesia, Thailand and the Philippines) between 1992 and 2006. Applying a new cointegration technique ${ }^{[12]}$, which takes into account the presence of a potential structural break, shows that ICT investment has had a positive and significant long-run relationship with economic growth in Australia, Malaysia and Singapore. However, in Indonesia, the Philippines and Thailand ICT investment did not contribute significantly to economic growth during the same period. These three countries have yet to reap the benefits of ICT. Our empirical results suggest that the three lagging ASEAN countries should increase their ICT investment in order to achieve sustainable economic growth in the new knowledgebased economy.
\end{abstract}

Key words: ICT, Australia, ASEAN-5 countries, economic growth

\section{INTRODUCTION}

Technological breakthroughs, especially in information and communication technologies (ICT), have brought unprecedented benefits to economies worldwide. The positive benefits created by ICT are observable in all sectors of the economy-in the ICTproducing sector as well as the ICT-using sector. Generally, ICT enhances business efficiency, enables swifter product market penetration, promotes superior labour productivity, creates avenues for rapid exchange of information, improves logistics and delivery systems and facilitates efficient service to customers. ICT allows countries to deal with the challenges pertaining to society, the economy and the environment. Effective management of these challenges, via ICT, can boost economic growth in any country.

Many studies examine the benefits brought in by ICT to an economy. The famous seminal research by Solow ${ }^{[34,35]}$, on the contribution of technology on productivity growth in the US, sparked great interest among scholars on the relationship between technology and economic progress. Since the late 1980s myriad studies have covered this issue, albeit with a slight amendment. Instead of looking solely at technological products, many examined the importance of ICT to economic progress, particularly in developed countries. Studies conducted before the mid 1990s did not find a significant relationship between ICT and economic growth $^{[3,18,23,33,37]}$.

Empirical studies on this issue conducted since the 1990s found a positive and significant relationship between ICT and the productivity/economic growth of developed countries, especially in the US ${ }^{[37]}$. In addition to the US, other developed economies have managed to tap into the intrinsic value of ICT. For example, countries such as Australia, Sweden, Finland and Ireland experienced significant productivity and economic expansion due to $\mathrm{ICT}^{[6]}$. Several Asian countries, namely Singapore, Japan, Korea and Taiwan, have also benefited greatly from ICT development ${ }^{[24]}$.

In the case of Australia, most studies focus on the relationship between ICT investment and labour productivity. According to Dunt and Harper ${ }^{[9]}$, investment in ICT has contributed positively to labour productivity in Australia. However, similar

Corresponding Author: Ali Salman Saleh, School of Applied Economics, Victoria University, Vic 8001, Australia Tel: +61399195271 Fax: +61399194888 
developments have not been witnessed in developing countries. For instance, Dewan and Kraemer ${ }^{[7]}$ found that the contribution of ICT to economic growth in developing countries was statistically insignificant, compared to developed economies. In another study, Pohjola $^{[31]}$ found that the rate of return from ICT in developing countries from the 1980s to the mid 1990s was less than $2 \%$, compared to $10 \%$ in developed countries during the same sample period. The lower return from ICT in developing countries is attributed to inadequate infrastructure to support ICT development in the economy. This problem is further compounded by the low ICT literacy level among the population $^{[24]}$.

Various reasons might be put forward to explain the weak relationship between ICT and economic growth in developing countries. However, our main concern is whether ICT investments in developing countries are undertaken strategically to take advantage of ICT, or if there is room for improvements in these countries' investment policies.

In the case of ASEAN countries, most (except Singapore) are still at the developing stage. With the exception of Laos, Vietnam, Myanmar and Cambodia (which are underdeveloped economies), the remaining ASEAN members have been investing in ICT applications and services since the 1980s. While the absolute sum of these investments is still low compared to more developed economies, the ICT-related initiatives undertaken by ASEAN countries nevertheless represent a statistically measurable amount on the returns from ICT investments. Australia, as indicated earlier, has invested heavily in the ICT sector, especially during the 1990s and 2000s.

This study empirically investigates whether ICT investments in Australia and the ASEAN-5 countries (Malaysia, Singapore, Indonesia, Thailand and the Philippines) contribute to economic growth from 1992 to 2006 .

\section{ICT DEVELOPMENT IN AUSTRALIA AND THE ASEAN-5 COUNTRIES}

This section reviews the importance of the ICT sector and its development in Australia and the ASEAN-5 counties and sheds light on key ICT-related strategies and policies implemented in these countries.

Since the 1990s Australia has enjoyed a dramatic increase in ICT adoption. This development has fostered an excellent environment for businesses to reap the benefits from such an adoption and transform the country into a knowledge economy. Australia was well ahead compared to OECD countries in terms of ICT expenditure as a percentage of GDP during the period 1992-1997. The investment rate increased from $7 \%$ in 1992 to $8 \%$ in 1997, which was well above the OECD average and higher than US, at $7.8 \%$. Annual growth in ICT investment was approximately $15 \%$ during the 1990s. It was lower than the US during this period, but higher compared to many other OECD countries ${ }^{[2]}$. Finance, communication and energy sectors (for example, water, gas and so on) invested heavily in ICT, while other sectors, such as agriculture, invested to a lesser extent. This may have been influenced by many factors, such as the size of the business, the importance of the sector in terms of export, among others factors.

The adoption of ICT by Australian households was high during 2000, when 50\% of Australian households owned personal computers (roughly equivalent to the US). According to the International Data Corporation ${ }^{[2]}$ Australia ranked eighth in the world, with America fourth and the Scandinavians countries on top. Also, Australia was among the top-three countries in Internet and computer infrastructure, next to Sweden and Singapore, while the US was placed tenth ${ }^{[2]}$.

The ICT sector in Australia continued to grow during the early 2000s, contributing \$A31 billion, or $4.6 \%$ of GDP. The major contributor for this sector was telecommunications services, which accounted for $50 \%$ of ICT-added value, followed by computing services $(24 \%)$, then ICT wholesale and retail (19\%). Equipment manufacturing only accounted for $7 \%$ during this period $^{[8]}$. During 1996-2001 expenditure on ICT in Australia grew by approximately $10 \%$ annually. During the early 2000s the ICT sector took up $24 \%$ of total research and development ( $R$ and $D)$ spending; while communication technologies and computer software accounted for $64 \%$ of business ICT $\mathrm{R}$ and $\mathrm{D}^{[8]}$. These figures indicate that the ICT sector in Australia is growing, becoming more competitive and now plays a vital role in terms of businesses development. ICT and the Internet in particular, enables consumers to have access to goods and services that might not be supplied through traditional retail outlets such as specialist music and books (Dunt and Harper, 2002). In other words, the Internet plays an important role as a mediator between buyer and sellers.

Australia's ICT sector plays an important role in boosting business transactions online and takes full advantage of its strong legal environment and security infrastructure in supporting business online. During 2000-2002 Australian businesses enjoyed a rapid increase in online businesses and online revenues almost doubled, accounting for \$A43 billion (approximately 33\% per year $)^{[8]}$. ICT and Internetbased business also play an important role in reducing 
transaction costs, producing cost savings. ICT utilisation among Australian businesses also grew rapidly over the last decade. According to a survey conducted by the Australian Bureau of Statistics (ABS) for the period 2000-2001, 84\% of all businesses that employed more than 20 people utilised computers; $69 \%$ of these accessed the Internet and $22 \%$ had websites ${ }^{[27]}$.

Turning to the ASEAN-5 countries, Singapore is one of the most advanced and has been a leading knowledge economy for the last thirty years or so. Singapore has implemented strategic ICT policies since the late 1970s. For example, one of the earliest efforts to modernise the country involved the creation of a five-year Civil Service Computerization (CSC) program in 1981. The main focus of this plan was to computerise government agencies to enhance productivity in government agencies ${ }^{[19]}$. In 1985 the National IT Plan (NITP) was implemented to strengthen the computerisation of the nation. This plan involved strong integration of the government and the private sector via electronic data interchange networks and the introduction of the Small Enterprise Computerisation Program (SECP) and Small Enterprise Computerised Accounting Program (SECAP) to help small and medium sized enterprises (SMEs) to upgrade their business operations and efficiency.

Singapore also focused on building domestic research and development capabilities in the country. To this end, the educational system was revamped to provide more ICT-related content in the syllabus. For example, the government phased out the British-based education system at the primary and secondary school level and incorporated a German-type education system-one that concentrated more on mathematical and technical competencies ${ }^{[19]}$.

In line with the changes in the global ICT landscape, the Singapore government developed a fourth strategic plan in 1999: Infocomm 21 (Information and Communications Technology for the 21 st Century). The primary role of Infocomm 21 was to prepare the local ICT sector to face greater competition from global industries. In July 2000 SingTel (a government-linked telecommunications company) liberalised the asynchronous digital subscriber line (ADSL). Also, the Information-Comm Development Authorities (IDA) introduced their Open Policy in 2002, which focused on further opening up the broadband services in Singapore ${ }^{[1]}$.

Since the mid 1980s Malaysia, another ASEAN5 country, has taken various initiatives to transform itself into a knowledge economy. Technology Park Malaysia (TPM) was established in 1988 with the purpose of assisting the development of local technologies and commercialising $\mathrm{R}$ and $\mathrm{D}$ findings. The primary role of the TPM is to support growth of ICT industrialisation and become an interface between industry, government, research institutes and universities in Malaysia. In 1992 the Malaysian Technology Development Corporation (MTDC), a joint venture organisation between government and the industry, was established. The MTDC's role is to promote the commercialisation of local research projects and monitor the development of venture capital funding in the country ${ }^{[21]}$. The National IT Council (NITC) was created in 1996, which was intended to become the main ICT policy making body in the country. In the same year NITC launched the National IT Agenda (NITA), which served as the main framework for the systematic development of ICT in Malaysia.

Among the major initiatives framed under the NITA was the formation of the Multimedia Super Corridor (MSC) in 1996. The MSC leverages ICT to provide a conducive environment for the development of creativity and innovation in the country, by providing a favourable operating environment for local and foreign ICT-based companies, with the objective of enabling faster technology transfer and quicker ICT adoption in Malaysia. Apart from being a centre for technology transfer, the MSC also aims to build up local content development. To this end, seven flagships were introduced under the MSC, including electronic government, the smart school system, a multipurpose card system, telehealth, a research and development ( $R$ and D) cluster, e-commerce and technoprenuer ${ }^{[25]}$. At present, each flagship is at different stages of development.

Apart from the MSC, Malaysia also implemented strategic science and technology ( $\mathrm{S}$ and $\mathrm{T}$ ) policies which promote technological innovation and economic development in the country. The various Malaysian plans concentrate on increasing the research and development ( $R$ and $D$ ) activities of both the private and public sectors. Funding mechanisms for R and D activities, especially in the areas of ICT, have increased over the years. The Intensification of Research in Priority Areas (IRPA) fund was introduced in 1987. Initially, this fund was meant only to support public sector R and D projects. However, IRPA funding was later extended to $\mathrm{R}$ and $\mathrm{D}$ projects undertaken by the private sector. In each successive Malaysian plan, funding allocation for IRPA increased substantially. For example, under the 5th Malaysian Plan (1986-1990) a total of RM414 $\mathrm{m}$ was allocated. Under the 6th Malaysian Plan (1991-1995) a total of RM589 m was allocated for IRPA programs. This subsequently 
increased to RM755 under the 7th Malaysian Plan and RM1 billion under the 8th Malaysian Plan ${ }^{[22]}$.

In the case of the Philippines, in the early 1960s the government took steps to embrace the knowledge economy, with particular emphasis on computerising the country. In 1971 the National Computer Centre (NCC) was established to computerise the government $^{[41]}$. In 1994 the Philippines implemented the National Information Technology Plan (NITP)-their main ICT strategic plan to catapult the country into the information age.

In February 1998 the Philippines implemented the National Information Technology Plan (IT21), which provides the vision and strategy to bring the country into the new economy. In 1999 the Department of Trade and Industry announced their ISP.COM, an internet strategy for the Philippines which focuses on attracting direct foreign investment in the ICT industry and ICT-enabled services ${ }^{[38]}$. In 2000 the Government Information Systems Plan (GISP) was implemented in the Philippines. The GISP's aims were to create a system of governance that would lead to faster and better delivery of public goods and services, greater transparency in government operations, increased capacities of public sector organisations and proactive participation of citizens in governance ${ }^{[40]}$.

In terms of human capital development, the Philippines have adopted several plans which provide free computer access in schools. In 1999 Microsoft provided free PCs to high schools under their Philippines Connected Learning Community (CLC) program $^{[13]}$. In 2000 the Personal Computers for Public Schools Program was launched. Benefiting from a loan of $\$ 11.75 \mathrm{~m}$ from Japan, the government donated new or secondhand computers to nearly 1,000 schools in the country. Each school was given 20 PCs and free ICT training and support ${ }^{[45]}$ and the Foundation for Information Technology Education encouraged telecommunication firms to donate free Internet service to 1,000 schools in the Philippines ${ }^{[10]}$.

In contrast, the development of the knowledgebased economy in Indonesia began with the liberalisation of the telecommunication sector, that is, PT Telekomunikasi Indonesia (Telekom) and PT Indonesian Satellite Corporation (Indosat) in the early 1990s. During this period the mobile telecommunication market also strengthened when the Mobisel (a Telekom joint venture company) launched an analogue NMT network in Indonesia. Another analogue AMPS network, Nacional, was launched in the country in 1991.

In October 1996 Excelcomindo (a private telecommunication company) launched the GSM network service in Indonesia, marking the beginning of the mass mobile service in the country. In July 1999 Indonesia launched its Blueprint of the Indonesian Government's Policy on Telecommunications. The Blueprint provides measures to improve the telecommunication sector via liberalisation and regulatory transparency. At end of 2000 there were seven mobile phone operators in Indonesia ${ }^{[13]}$.

In 1996 the National Steering Committee for IT Competitiveness (Nusantara-21) was created to drive Indonesia's ICT development. The World Bank provided a $\$ 35 \mathrm{~m}$ loan for the Nusantara-21 project. Specifically, this project aimed at creating a national information infrastructure, the development of multimedia applications and the establishment of public access points $^{[13]}$.

In 2001 the Utilisation of Computer with Application Programs in Indonesian Language Program was implemented, with the objective of creating computer software in Indonesian, important because of the low numbers of English-literate people in the country. The ICT training in schools program was implemented in 2001, to train teachers and students using ICT, especially the Internet. In September 2002 Indonesia conducted a computer-assisted learning media training program for 800 high school teachers from 200 schools $^{[44]}$. The private sector has also contributed significantly in educating the public in ICT awareness. In 2001 the Millennium Internet Roadshow was conducted by the Association of Indonesian Internet Service Providers in nearly 15 provinces in Indonesia.

Similar to developments in some other ASEAN countries, the development of a knowledge-based economy in Thailand is still in its infancy. In 1986 the National Electronics and Computer Technology Centre (NECTEC) was created in Thailand, responsible for promoting ICT as a tool for economic expansion [Tipton, 2002]. Since July 2000 Thailand has been promoting the e-Thailand framework, aimed at strengthening national competitiveness through ICT usage. In November 2000 the government endorsed the e-Thailand framework, with a specific focus on esociety, e-government, e-trade, e-service, e-investment, e-commerce and information infrastructure ${ }^{[25]}$.

In recent years, several other key initiatives have been undertaken in national ICT development in Thailand, for example, SchoolNet Thailand, the Government Information Network (GINet) and the Software Park project. The SchoolNet Thailand project aims to increase ICT usage in the Thai education system. Here, Internet access in Thai schools is free of charge. By early 2001 2,184 schools in Thailand had 
Internet access and 673 schools had their own websites $^{[42]}$.

To stimulate e-commerce activities in Thailand, the government created a commercial trade website ${ }^{[43]}$ in 1999, with a specific focus on B2C and B2B transactions. More recently, the Thai Dot Com website was created by the Internet Thailand Company to provide free web hosting for e-commerce services to business partners. In March 2002 the Thai government endorsed a policy framework for Thailand ICT development for 2001-2010. The IT2010 policy set key development objectives for exploiting the benefits of information and communications technology to transform Thailand to a knowledge economy.

\section{A BRIEF LITERATURE REVIEW ON ICT AND ECONOMIC GROWTH}

Various studies have examined the relationship between ICT and economic growth, particularly in the 1990s. However, in general, most of these covered developed economies, with limited attention given to developing nations.

Lau and Tokutsu ${ }^{[16]}$ examine the relationship between ICT and economic growth in the US over the period 1960 to 1990 using the production function approach. They found that ICT had contributed to nearly half of the national output during the study period. Kraemer and Dedrick ${ }^{[15]}$ examine the impact of ICT on economic growth in eleven Asia Pacific countries for the period 1983 to 1990. Again using the production function approach, they found a significant and positive relationship between ICT and economic growth, particularly in countries that had invested heavily on ICT, such as Singapore, Korea and Japan.

Niininen $^{[26]}$ estimates the contribution of ICT to Finland's economic growth over the period 1983 to 1996 using the growth accounting framework. That study decomposes economic growth into portions attributed by capital, labour and multifactor productivity. The author later augments it to include the effects of ICT (that is, computer hardware, software and computer labour) on economic growth. The empirical results show that compared to the other factors, ICT stood out as a greater influence on economic growth in Finland.

Daveri $^{[6]}$ examines the contribution of ICT on economic growth in eleven OECD countries. Using the growth accounting framework, the author found that ICT contributed significantly to economic growth of most OECD countries, especially during the mid 1990s and concluded that all the sample OECD countries gained economically from ICT investment over the years.
Again using the growth accounting framework, Oulton $^{[28]}$ examines the contribution of ICT to economic growth in the UK over the years 1989 to 1998. ICT capital was separated into computers, software, telecommunications equipments and semiconductors. The empirical result highlights that ICT had significantly contributed to economic growth in the UK, especially from 1994 to 1998.

Colecchia and Schreyer ${ }^{[5]}$ estimate the contribution of ICT on output growth in nine OECD countries over the period 1980 to 2000. Their empirical results show that ICT contributed between 20 and $50 \%$ of the national output growth over the study period in most countries. This increased to $30-90 \%$ per annum in the mid 1990s.

Piatkowski $^{[30]}$ investigates the impact of ICT on economic growth in Poland over the period 1995 to 2000 using the growth accounting framework. This study found that ICT investment contributed nearly 9\% of Poland's economic growth during the sample period. The author associates such finding with the increased investment in ICT over the period 1993 to 2001 in the country, largely due to a continuous decline in ICTbased products and services prices.

Mas and Quesada ${ }^{[20]}$ used data on ICT investment and examine its contribution to economic growth in Spain from 1985 to 2002. The authors segregate the economy into four sectors, namely: the intensive ICTusing sector, the non-intensive ICT-using sector, another non-intensive ICT-using sector and the nonmarket sector. Their results show that ICT had a strong impact in the intensive ICT-using sector compared to the other three sectors. Overall, the impact of ICT on the economy was rather found to be small during the study period.

In summary, nearly all major studies undertaken since the mid 1990s show positive and significant returns on ICT investment. The majority of studies employed the production function and the growth accounting framework to quantify the contribution of ICT to economic growth. However, these methods attract criticism. For instance, Pohjola ${ }^{[32]}$ highlights that the growth accounting framework only yields a mechanical decomposition of the growth of output into the growth of inputs and multifactor productivity. This method cannot relate the changes in inputs and productivity to the more fundamental elements of the economy, such as technology and government policies.

Many existing studies do not concentrate on the issue of time series problems, such as that of spurious regression. More specifically, the existence of nonstationary and stationary time series variables is often neglected. As Granger and Newbold ${ }^{[11]}$ highlight, if this 
assumption is not satisfied, the estimated results may be spurious. Lee and Gholami ${ }^{[17]}$ argue that while nonstationary variables may show no cointegration, an assumption is made that no long-run relationship exists between the variables. However, the ordinary least square regression results may still show significant relationships between the variables.

In order to alleviate the above-mentioned issues, this study uses the Gregory-Hansen ${ }^{[12]}$ cointegration approach to gauge the contribution of ICT to economic growth in Australia and the ASEAN-5 countries. The $\mathrm{GH}$ procedure is appropriate for small sample size studies such as the current one. The cointegration approach used conventionally ${ }^{[14]}$ requires a large sample size.

\section{DATA AND METHODOLOGY}

This study uses two factors: ICT investment per capita, while the real GDP figure per capita (a proxy for economic growth). Both factors are in US dollars(\$US). The ICT per capita data for Australia and the ASEAN-5 countries are taken from the Digital Planet Report ${ }^{[39]}$, while real GDP per capita data is taken from the Business Monitor Online Database ${ }^{[4]}$. The sample period for this study is from 1992 to 2006 . ICT data for ASEAN countries is only available from 1992 onwards.

As per the objective of this study, our analytical framework is based on previous studies, including Lau and Tokutsu ${ }^{[16]}$ Niininen ${ }^{[26]}$ Oulton ${ }^{[28]}$ and Piatkowski ${ }^{[30]}$. These examine the impact of ICT on economic growth in various countries using the growth accounting framework. The following functional model is specified for Australia and the ASEAN-5 countries:

$$
\mathrm{RGDP}_{\mathrm{t}}=\beta_{0}+\beta_{1} \mathrm{ICT}_{\mathrm{t}}+\varepsilon_{\mathrm{t}}
$$

Where:

$$
\begin{array}{ll}
\text { RDGP }_{\mathrm{t}} & =\text { Real GDP per capita, US\$ (m) } \\
\mathrm{ICT}_{\mathrm{t}} & =\mathrm{ICT} \text { investment, US\$ }(\mathrm{m}) \\
\varepsilon_{\mathrm{t}} & =\text { Error term }
\end{array}
$$

The gregory-hansen cointegration technique with a potential structural break: Many previous empirical studies ignore the issue of the existence of potential structural breaks in cointegration relationships. However, the Gregory-Hansen approach addresses the problem of estimating cointegration relationships in the presence of a potential structural break by introducing a residual-based technique. This tests the null hypothesis (no cointegration) against the alternative of cointegration relationship in the presence of a potential break.

While conventional cointegration techniques (such as the Engle-Granger or Johansen-Jeslius procedures) do not consider the existence of potential structural breaks at all, the advantage of the Gregory-Hansen methodology is that this testing procedure determines the time of the break endogenously. In other words, in this approach, the break point (TB) is unknown and is determined by finding the minimum values for the ADF t-statistic. Using the Gauss program, the optimal number of lags can be selected automatically by a general-to-specific SBC (Schwarz Bayesian Criterion).

The ADF t-test was extended by GregoryHansen $^{[12]}$ in order to test the null hypothesis of a no cointegration relationship against the alternative: that a cointegration exists in the presence of a potential structural break. By taking into account the existence of a potential unknown and endogenously determined onetime break, the GH approach allows for structural shifts in either the intercept alone, in both the trend and the level shift, or for a full break.

This study considers a full break model, because it is less restricted to other two cases in the GH model. We follow the GH full break approach, which includes two dummy variables (one for the intercept and one for the slope), without including trend in the model. This model allows for change in both intercept and slope, as illustrated below:

$x_{1 t}=\mu_{1}+\mu_{2} D U_{t}+\alpha_{1}^{\prime} x_{2 t}+\alpha_{2}^{\prime} x_{2 t} D U_{t}+e_{t} t=1, \ldots ., n$

In the above equations, $\mathrm{Du}_{\mathrm{t}}=0$, if $\mathrm{t} \leq \mathrm{n} \tau$ and $\mathrm{Du}_{\mathrm{t}}=1$ if $\mathrm{t}>[\mathrm{n} \tau]$, where the unknown parameter $\tau \in(0,1)$ is defined as the relative timing of the change point. The cointegration slope coefficient before the regime shift is denoted by $\mathrm{a}_{1}$ and change in the slope coefficient is denoted by $\alpha_{2}$. Finally, $\mu_{1}$ represents the intercept before the level shift and the change in the intercept at the time of the shift is represented by $\mu_{2}$.

\section{EMPIRICAL RESULTS BASED ON THE GREGORY-HANSEN (GH) PROCEDURE}

We now apply the GH approach in order to determine the time of the structural break endogenously. This also tests for the existence of cointegration relationships among our variables of interest for different countries in the sample. Among the above-mentioned $\mathrm{GH}^{[12]}$, three cases of 
cointegration with a structural break. The empirical result ${ }^{1}$ based on the $\mathrm{GH}$ cointegration procedure (full break), indicates that the reported statistics for Australia, Singapore and Malaysia are-5.20578,5.07946 and-6.36956 respectively. These are actually smaller than its respective $5 \%$ critical values (the critical value is-4.95 at the $5 \%$ significance level). This confirms the rejection of the null hypothesis of no cointegration in favour of the existence of a cointegration relationship in the presence of a structural break.

In comparison, for Indonesia, Thailand and the Philippines, the empirical results indicate that the reported statistics are $-3.58044,-2.95918$ and -2.74762 respectively. These are larger than its respective $5 \%$ critical values (the critical value at the $5 \%$ level is -4.95). This confirms the non-rejection of the null hypothesis of no cointegration in favour of the existence of a cointegration relationship in the presence of a structural break.

As shown in Fig. 1, the most important structural break in the Australian economy took place in 2000, which was identified endogenously by the $\mathrm{GH}$ procedure. The time of the break is associated with the huge investment in ICT, which took place during 2000. Australia's ICT sector contributed \$A31 billion during 2000-2001 $1^{[8]}$.

For Singapore and Malaysia (Fig. 2, 3) the time of the break coincides with the effect of the East Asian financial crisis. For example, the collapse of the Thai currency in July 1997 had a severe impact on the Malaysian economy as well as on its currency ${ }^{[29]}$. In the case of Indonesia and the Philippines (Fig. 4, 6), the time of the break coincides with that government's ICT strategy during 1999. For example, the Philippines initiated and implemented their Internet strategy to

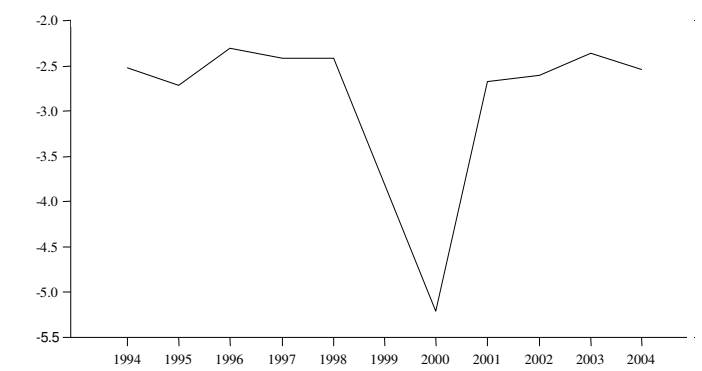

Source: Authors' calculations based on the GH [12] procedure (full break model). TB: 2000

Fig. 1: Plots of the GH cointegration test (Australia) attract FDI and increase investment in ICT and ICTrelated services. In Indonesia, the government launched the Blueprint of the Indonesian Government's policy on Telecommunications. By the end of 2000 there were seven mobile phone operators in Indonesia ${ }^{[13]}$. This is considered as a very good initiative by a developing nation.

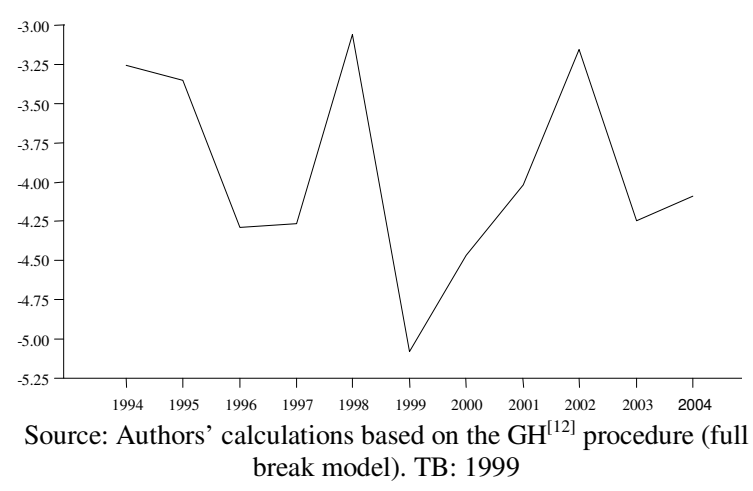

Fig. 2: Plots of the GH cointegration test (Singapore)

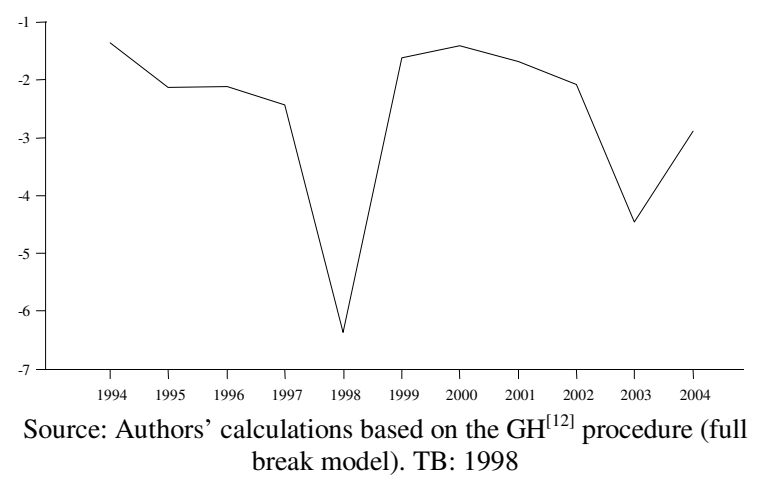

Fig. 3: Plots of the GH cointegration test (Malaysia)

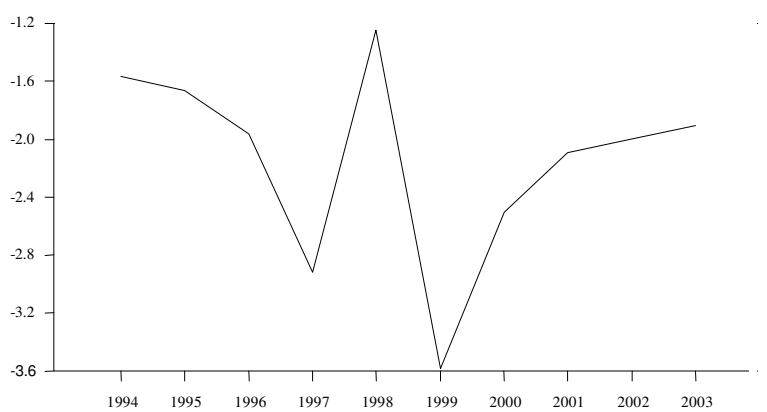

Source: Authors' calculations based on the $\mathrm{GH}^{[12]}$ procedure (full break model). TB: 1999

Fig. 4: Plots of the GH cointegration test (Indonesia) 


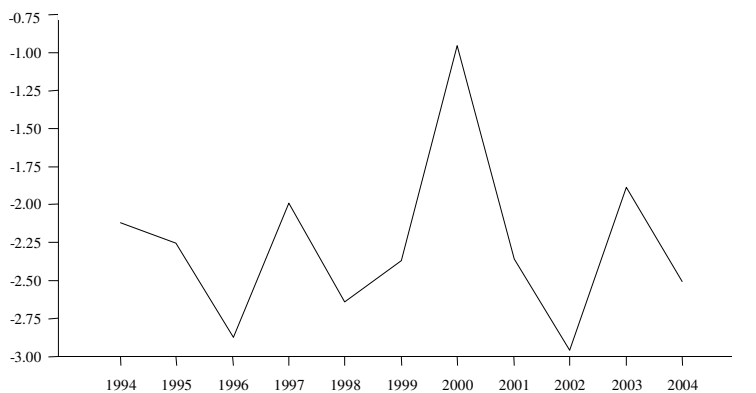

Source: Authors' calculations based on the $\mathrm{GH}^{[12]}$ procedure (full break model). TB: 2002

Fig. 5: Plots of the GH cointegration test (Thailand)

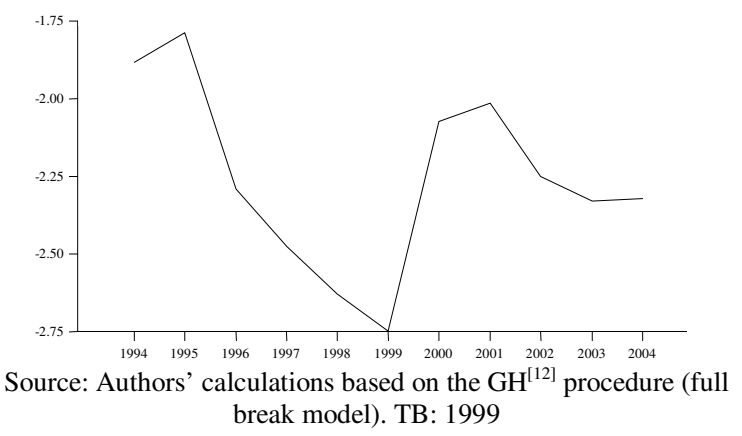

Fig. 6: Plots of the GH cointegration test (Philippines)

Figure 5 shows that in Thailand, the time of the break (2002) coincides with the results of implementing the e-Thailand framework (which focused on e-society, e-government, e-trade and so on-see ${ }^{[25]}$. The year 2002 witnessed strategic alliances between many educational systems in the country and the adoption of ICT was rapidly growing during this period.

\section{CONCLUSION AND POLICY IMPLICATIONS}

The empirical results from the GH model show that ICT had positive and significant long-run implications for the economic growth of Australia, Malaysia and Singapore between 1992 and 2006. The result coincides with government policies and strategic directions undertaken in Australia, Malaysia and Singapore which aimed to informatise the economies by increasing ICT diffusion and creating innovative business markets to produce new products and services. These policies subsequently enhanced economic growth in the three countries.

In the Philippines, Indonesia and Thailand, however, the empirical results show no cointegration between ICT and economic growth. In other words,
ICT did not contribute significantly to economic growth over the sample period in these countries. The ICT adoption rate was moderate or low and the rate of technology transfer in these economies was also low. This implies that these countries are lagging behind and need to invest more in ICT.

Particularly for Indonesia, the results are not surprising, given that the country is heavily reliant on the agricultural sector. The technological advancement in Indonesia is dismal and hence there is a low level of ICT-related investment. ICT-based investment has minimal relevance to the growth of the Indonesian economy.

Based on these results, we now offer some policy recommendations. While Australia, Malaysia and Singapore appear to be headed in the right direction, the Philippines, Thailand and Indonesia immediately need to enter the race towards economic competitiveness leveraged on ICT. Economic competitiveness today is not only about having abundance of natural resources, but also about how adept the country is at technological development.

In many developing countries, significant proportions of the population cannot afford ICT services due three major factors. Income levels in these countries are low; the cost of ICT services is significantly higher than in developed countries; and public facilities that provide affordable ICT services are limited. To overcome these problems, developing ASEAN countries should have a clear and coherent ICT development policy.

An integral part of this policy should be a multistrategy, cost-effective ICT infrastructure plan. This should include a combination of a conventional wired telecommunications service, along with a wireless service and a digital power line (DPL). Fixed telephone lines have been an important part of the ICT infrastructure in many developed countries and fixed line technology (the old telephone network using coaxial cable) has helped developed countries stay competitive in the global economy over the last five decades. Lagging ASEAN countries need to invest more to upgrade their ICT infrastructure, including basic and advanced telephone networks, an Internet backbone, interconnection and access points.

Developing ASEAN countries also need to increase personal computers (PC) ownership. One measure to achieve this accessibility to ICT services is through the promotion of public community centres, which could be located in school, universities, public libraries, post offices and government hospitals. To keep ICT services affordable, users should only be charged the local telephone access cost. Commercial 
Internet and cyber cafés can also play an important role in providing affordable ICT access. The number of commercial Internet and cyber cafés is significantly lower in most developing countries compared to that in developed countries. To improve access to ICT services, governments in the underdeveloped countries should encourage the private sector to establish commercial cyber cafés. The private sector's participation in providing ICT services will also reduce the government burden in providing such services.

\section{REFERENCES}

1. Ang, P.H., Q. Zhou and Y. Jiang, 2003. Lessons in broadband adoption from singapore. J. Interactive Advertising, 4 (1).

2. Banks, G., 2001. The Role of ICT in Australia's Economic Performance. Online: www.pc.gov.au/speeches/cs20010926/cs20010926. pdf, [08/10/2006].

3. Berndt, E.R., C.J. Morrison and L.S. Rosenblum, 1992. High tech capital formation and labour composition in us manufacturing industries: An explanatory analysis, NBER Working Paper No. 4010.

4. Business Monitor Online, 2007. Macroeconomic Data. Online: http://www.businessmonitor.com, [10/01/2007].

5. Colecchia, A. and P. Schreyer, 2002. ICT investment and economic growth in the 1990s: Is The United States a Unique Case? Rev. Econ. Dyn., 5: 408-442.

6. Daveri, F., 2000. Is Growth an Information Technology Story in Europe Too? Working Papers 168, IGIER, Bocconi University.

7. Dewan, S. and K.L. Kraemer, 2000. Information Technology and Productivity: Evidence from Country Level Data. Manage. Sci., 46 (6).

8. DFAT, 2002. Connecting with Asia's Tech Future: ICT Export Opportunities. Online: http://www.dfat.gov.au/publications/catalogue/asia s_tech_future_ict.pdf, [05/11/2006].

9. Dunt, E.S. and I.R. Harper, 2002. E Commerce and the Australian Economy. Econ. Record, 78 (242): 327-342.

10. Education News, 2001. 1000 Schools Nationwide Benefit from PCs for Public High Schools Program. Online: www.deped.gov.ph/ENjanHDL. htm, [05/01/2007].

11. Granger, C.W.J. and P. Newbold, 1974. Spurious regressions in econometrics. J. Econ., 2: 111-120.

12. Gregory, A.W. and B.E. Hansen, 1996. Residualbased tests for cointegration in models with regime shifts. J. Econ., 70 (1): 99-126.
13. International Telecommunication Union (ITU), 2002. Pinoy Internet: Philippines Case Study. Online: www.itu.int, [10/05/2006].

14. Johansen, S. and K. Juselius, 1990. Maximum likelihood estimation and inference on cointegration, with applications to the demand for money. Oxford Bulletin of Economics and Statistics, 52: 162-210.

15. Kraemer, K.L. and J. Dedrick, 1994. Payoffs from investment in information Technology: Lessons From the Asia-Pacific Region. Online: http://repositories.cdlib.org/cgi/viewcontent.cgi?art icle $=1116$ and context $=$ crito, [20/01/2007].

16. Lau, L.J. and I. Tokutsu, 1992. The Impact of computer technology on the aggregate productivity of the United States: an indirect approach, unpublished working paper, Stanford University, USA.

17. Lee, T.S.Y. and R. Gholami, 2001. Information technology and economic growth: A time series analysis, Working Paper 2001, National University of Singapore.

18. Loveman, G.W., 1994. An Assessment of the Productivity Impact of ICT. In: Information Technology and the Corporation of the 1990s: Research Studies, Allen, T.J. and M.S. Scott (Eds.). Oxford University Press, Cambridge, UK.

19. Low, L.S. and T.W. Toh, 1991, Economics of Education and Manpower Development: Issues and Policies in Singapore, McGraw Hill Book Company.

20. Mas, M. and J. Quesada, 2005. ICT and Economic Growth: A Quantification of Productivity Growth in Spain 1985-2002. OECD Statistics Working Paper, STD/DOC, 2005 (4): 1-56.

21. Mastic-Malaysian Science and Technology Information Centre, 2000, 1998 National Science and Technology Databook, Ministry of Science, Technology and Innovation, Government of Malaysia.

22. Ministry of Finance Malaysia, 2001-2005. Eight Malaysian Plans.

23. Morrison, C.J and E.R. Berndt, 1991. Assessing the Productivity of Information Technology Equipment in US Manufacturing Industries, National Bureau of Economic Research Working Paper 3582: MA.

24. Nair, M., M. Kuppusamy and R. Davison, 2005. A longitudinal study of the global digital divide problem: Strategies to close cross-country digital gap. The Business Review, Cambridge, 4 (1): 315-326. 
25. National Information Technology Committee (NITC), 2000. E-Thailand Initiative. Online: www.nitc.go.th/eThailand/initiative, [10/12/2006]

26. Niininen, P., 1998. Computers and Economic Growth in Finland. Working Paper: 148, UNU/WIDER.

27. NOIE, 2002. Contribution of ICT to Economic Growth. Online: http://archive.dcita.gov.au/_data/ assets/pdf_file/10438/Contribution_of_ICT_to_eco nomic_growth.pdf, [15/11/2006].

28. Oulton, N., 2001. ICT and Productivity Growth in the United Kingdom. Bank of England Working Paper. Online: www.bankofengland.co.uk/ workingpapers/index, [12/11/2006].

29. Pahlavani, M., A.S. Saleh and G. Sivalingam, 2006. Time series analysis of multiple structural breaks in the malaysian economy. The Middle East Business and Economic Review, 18 (2): 1-13.

30. Piatkowski, M., 2003. The contribution of ICT investment to economic growth and labour productivity in Poland 1995-2000. TIGER Working Paper Series No. 43, July 2003.

31. Pohjola, M., 2000. Information Technology and Economic Growth: A Cross-Country Analysis, WIDER Working Paper No. 173.

32. Pohjola, M., 2002. The new economy in growth and development. Oxford Review of Economic Policy, 18: 380-396.
33. Roach, S.S., 1987. America's technology dilemma: A profile of the information economy. Morgan Stanley Special Economic Study, April.

34. Solow, R., 1956. A Contribution to the theory of economic growth. Q. J. Econ., 70 (1): 65-94.

35. Solow, R.M., 1957. Technical change and the aggregate production function. Review of Economics and Statistics, 39 (3): 312-20.

36. Stiroh, K.J., 2002. Measuring Information Technology and Productivity in the New Economy. World Econ., 3 (1).

37. Strassmann, P.A., 1990. The business value of computers: An executive's guide. Information Economics Press, New Canaan, CT.

38. Tipton, F.B., 2002. Bridging the Digital Divide in Southeast Asia. ASEAN Economic Bulletin, 19 (1): 83-99.

39. WITSA (various years), The Digital Planet Report, WITSA Publication.

40. www.neda.gov.ph/GISP.

41. www.ncc.gov.ph.

42. www.school.net.th.

43. www.thaiecommerce.net.

44. Yuhetty, H., 2002, ICT and education in Indonesia, Online: www.gauge.u-gakugei.ac.jp, [20/11/2006].

45. ZDNet Asia, 2001. Japan PC fund outfits Philippine schools. Online: www. zdnetasia.com, [10/01/2007]. 